\title{
Counterfeit Aldines and Italic-Letter Editions Printed in Lyons 1502-I 5 10: Early Diffusion in Italy and France
}

\author{
William Kemp ${ }^{\dagger}$
}

From their initial appearance in April I 50I, it is clear that Aldus's italic-letter, octavo editions were an immediate success among the educated, the amateurs of bonae literae. In spite of the existence of various privileges obtained from the Venetian Republic and from the papacy in Rome covering both the editions and their new cancellaresca-style type, at least three printing houses had italic type and were printing the very same, or the same sort of octavo editions of classical texts without commentary by the end of $1503 .^{\text {I }}$ Given the financial outlay that such counterfeiting must have involved, it is not surprising that several of the instigators were, in fact, from important publishing houses, to wit, the Giunti in Florence and Venice, and the de Gabiano in Lyons (but with family connections in Venice.) ${ }^{2}$ For Aldus (and his major financial partner, Torresani), it must have been particularly disturbing to discover that the Lyonese were copying his new italic editions line by line, including the prefaces and dedicatory epistles bearing his name.

He even took his case to the educated public. Two years after printing his first italic-letter edition, in March 1503, he printed 'ex Neacademia nostra' a broadside, the 'Monitum,' or Warning, denouncing the Lyonese counterfeit editions and indicating how to distinguish them from the real thing. ${ }^{3}$ As he noted, the Lyonese editions were undated and unsigned, nor did they show the Aldine dolphin and anchor device, which he displayed prominently in the lower right-hand corner of the broadside. In addition, their texts were full of errors, the type lacked ligatures ${ }^{4}$ and had a certain Gallicness (i.e. heaviness) about it, and the paper smelled. Aldus gave a list of their editions and cited easily verifiable inaccuracies in each case.

t William Kemp is a member of the Department of Philosophy at the Collège du Vieux Montréal in Montreal. 
While such a warning may have been of use to some buyers (or readers|, it hardly discouraged the Lyonese, who simply reprinted the editions mentioned by Aldus, correcting precisely those errors he had indicated in the 'Monitum.' From the viewpoint of the historian, this broadside is crucial since it gives us clear evidence of Aldus's irritation and a detailed list of criticisms; at the same time, it provides us with a list of the earliest Lyonese counterfeits, which - being without date - would not otherwise have been easy to identify. They are, in alphabetical order: CatullusTibullus-Propertius, Horace, Juvenal-Persius, Lucan, Martial, Terence, and Virgil. 5 Of Aldus's italic octavo imprints of 1501 and 1502 , the Lyonese had copied all but the 1502 Cicero (Epistolae familiares), Statius, Valerius Maximus, and the three volumes of Ovid, and the last two authors were to appear, in all likelihood, before the end of $1503 .{ }^{6}$

There is, however, one aspect of Aldus's manifesto that has not received sufficient attention. Of the seven italic-letter editions published by the Lyonese listed in the 'Monitum,' one was not a copy of an Aldine edition (see fig. I). Prior to I 503, many editions of Terence are known, but no such edition had been published by Aldus (the first Aldine Terence appeared in 1517, two years after Aldus's death). So it is all the more surprising that Aldus took almost half of the leaf to tell us that the Lyonese have not used the oldest manuscript, that their text is bad, and that their metrics are all mixed up. He goes on to quote twelve lines of text from Terence. Although not an Aldine counterfeit, it would have been illegal to sell this edition within the jurisdiction of Venice since it was printed in an italic font, for which Aldus had obtained a ten-year privilege in March I 501 .

Of the seven earliest italic-letter, Lyonese imprints, three show an interesting typographical particularity: the front foot of the capital Rs have an elongated leg which goes below the base-line (see fig. 2)..$^{7}$ This $R$ is used consistently (without exception) throughout the first edition of Juvenal-Persius, in all quires except the first in the Virgil, and in the first quire of Terence. In the other four editions, a new $R$ with a fatter leg which stops at the base-line was introduced. Most but not all of what appear to be the earlier Rs were subsequently eliminated. In the case of the Virgil, the distribution of the two Rs is consistent in the two copies I have examined, suggesting either that the volume was printed from back to front, or that, for some reason, the first quire was reprinted later on. ${ }^{8}$

As for the Terence, the situation is as follows. The only copy I know 


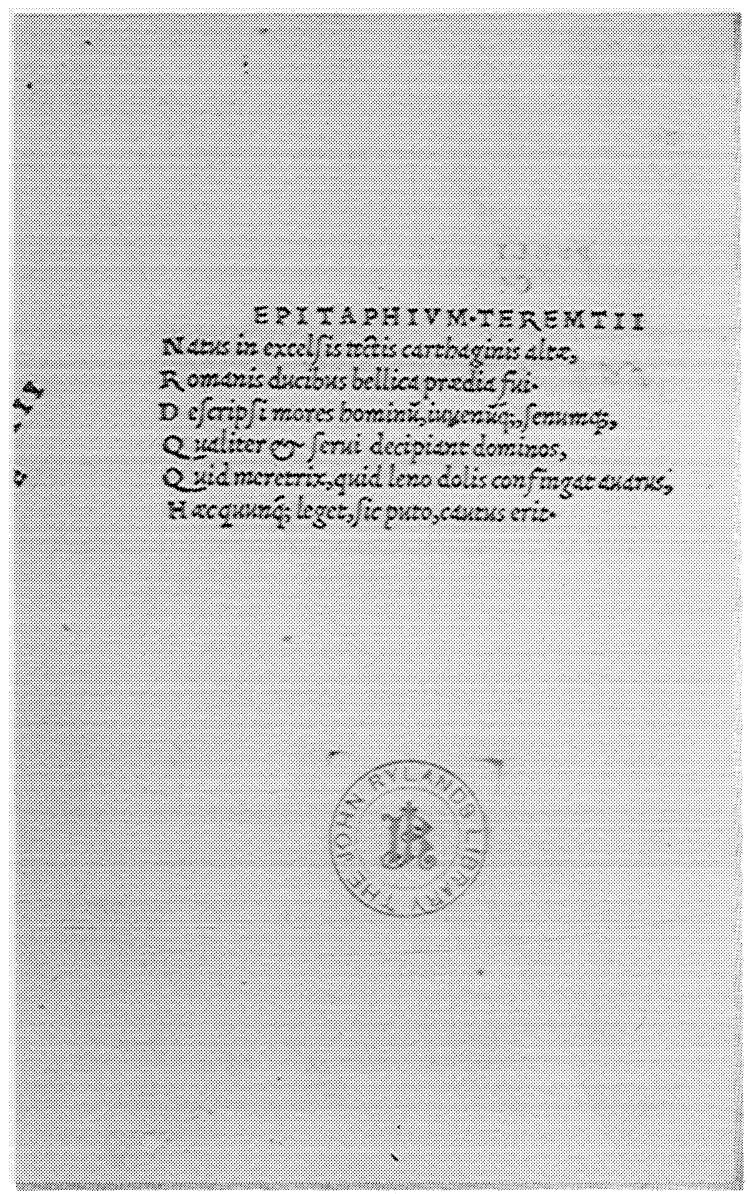

I. Verso of the title page of the first Lyonese edition of Terence's Comedie (c. I 502), showing errors mentioned by Aldus in the I 503 'Monitum': TEREMTII, praedia (line 2) and quunq[ue] (line 6). (Reproduced by courtesy of the Director and University Librarian, The John Rylands University Library. Shelf-mark: 20997.) 


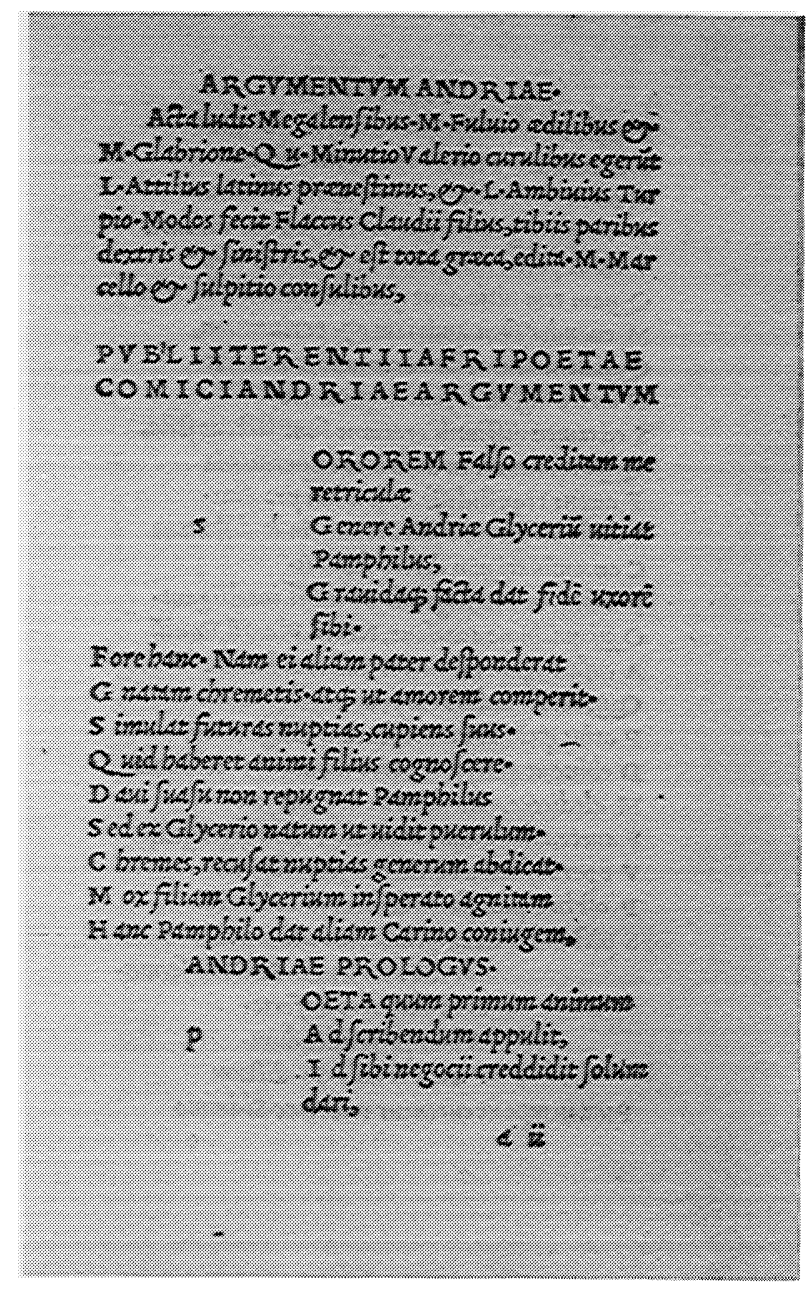

2. Opening page (sig. a2 $^{\mathrm{r}}$ ) of the first Lyonese edition of Terence's Comedie (c. 1 502).

(Reproduced by courtesy of the Director and University Librarian, The John Rylands University Library. Shelf-mark: 20997. Leaf size 152 x 96 mm.) 
of is held by the John Rylands University Library in Manchester. The first quire, with its long-legged Rs, contains the errors mentioned by Aldus. The following quires show basically the second, fat-footed R. Is this a complete copy of the first Lyonese italic-letter edition of Terence, or is it a composite edition comprising one quire from the first edition and the other quires from an otherwise unrecorded second edition with corrections? ${ }^{9}$ For the time being, we must assume that it represents a complete edition. If that is in fact the case, the order in which the earliest Lyonese italic-letter imprints were finished would appear to be Juvenal-Persius, Virgil, and Terence, followed by the others. Thus, if most of the earliest Lyonese italic-letter editions are counterfeits, or 'pseudo-Aldines,' one of the first three editions is a 'quasi-Aldine,' that is, an edition derived from a non-Aldine edition but printed in a (protected) italic. ${ }^{10}$ So, it is evident that, from the start, the Lyonese had grasped the essence of the new Aldine principle. The combination of italic type, text alone, and octavo format could be applied to any classical text: poetry, above all, but also prose; ancient texts, but also the more prestigious (or pretentious) modern writers. ${ }^{\text {II }}$

Between 1502 and 1510 , that is, during the years covered by Aldus's privileges, the Lyonese ${ }^{12}$ cranked out roughly fifty separate italic-letter editions /counting each volume printed in the case of multi-volume publications such as the three volumes of Ovid). These include three editions of Catullus et al., Juvenal, Martial, Terence (or perhaps twice), and Valerius Maximus, and two editions of selected works of Cicero, Horace, Lucan, Ovid (three volumes), Petrarch in Italian, Sallust, and Virgil. Single editions of the following texts also appeared: Aristotle (in three volumes including Theophrastus), Caesar, Cicero (Orationes), Cicero (Epistolae familiares), Euripides, Dante (perhaps twice), Justin, Philostratus, Pliny the Elder (two volumes), Prudence et al., and Xenophon. About $65 \%$ of this production involved reprints of Aldine editions $/ 33 / 5 \mathrm{I}){ }^{13}$ Three other editions (Caesar, Philostratus, and Xenophon) are copies of contemporary, roman-letter, Bologna editions. Finally, two editions (Sallust and a later Terence) were copied from italic editions produced in Florence by the Giunti.

Among the many questions such figures give rise to, I will concentrate on matters pertaining to the diffusion of the Lyonese italic-letter editions printed during the years when Aldus's privileges were still in effect, i.e. through 15 Io. Basically, we still do not know where they were sold. To begin with, I propose as a working hypothesis that during the first few years (roughly 150I-I505), 
readers north of the Alps would not have been immediately attracted to such imprints since the italic fonts were fairly far removed from the style of their handwriting and typography (basically gothic, or bastard gothic). It has been claimed (but see below) that Guillaume Le Rouge printed two editions for Denis Roce in Paris in a heavy italic (with gothic capitals) in about $1507-08$. But very few such editions were printed in Paris before the early I 520 s. $^{14}$ In Basle and in the Rhine Valley, similar types were not in use before I519-20. ${ }^{\text {I5 }}$

A further indication can be found in the total absence of any identification of printer, publisher, or place of imprint in the early Lyonese pseudo-Aldines. Since Aldus's privileges were only valid in Italy, specifically in the Veneto and in the Papal states, there would have been no need to suppress one's identity if the books were being sold in France. Only one of the editions printed up to 15 Io bears any name. In the dedicatory epistle to the 1508 Suetonius, a certain 'Balthasar' is mentioned (Balthasar de Gabiano) as well as the city of Lyons. But the reason almost certainly is that this is a quasiAldine and not a pseudo-Aldine. ${ }^{16}$ One of the Lyonese fleur-de-lys symbols, perhaps a printer's device, began to appear on some of the italic-letter imprints in 1510 , and the name of Barthelémy Trot shows up in colophons beginning in I5II, during the final year covered by Aldus's privileges. ${ }^{17}$

While this is not proof, it certainly does suggest that, in the early and most productive years, a large part of the Lyonese production must have been shipped to Italy, which would have comprised the largest (but also the most competitive) market for italic-letter editions. If so, given the number of editions up to I 5 IO and the number of copies printed /the figure of $I, 000$ is given in the epistle to the I 508 Suetonius), it should be possible to find signs of early Italian ownership in some of the copies of these editions. ${ }^{18}$

First, let us look at an illuminated copy. It is well known that a good number of copies of Italian incunabula contain hand-painted pages (frontispiece, title-page, first leaf, etc.). ${ }^{19}$ Although most were folios or quatros, there is evidence of illuminators working on smaller-sized volumes other than Books of Hours. Given the prestige of Aldus's new italic collection, it is not surprising to find illuminated copies, some even magnificently illuminated. ${ }^{20}$ There is one copy of the c. I504 Juvenal/Persius which appears to have been illuminated in Italy. This copy is held by The John Rylands University Library in Manchester. The first page of each of the two authors has been hand-painted (see fig. 3 ). ${ }^{21}$ This sort of flower and 


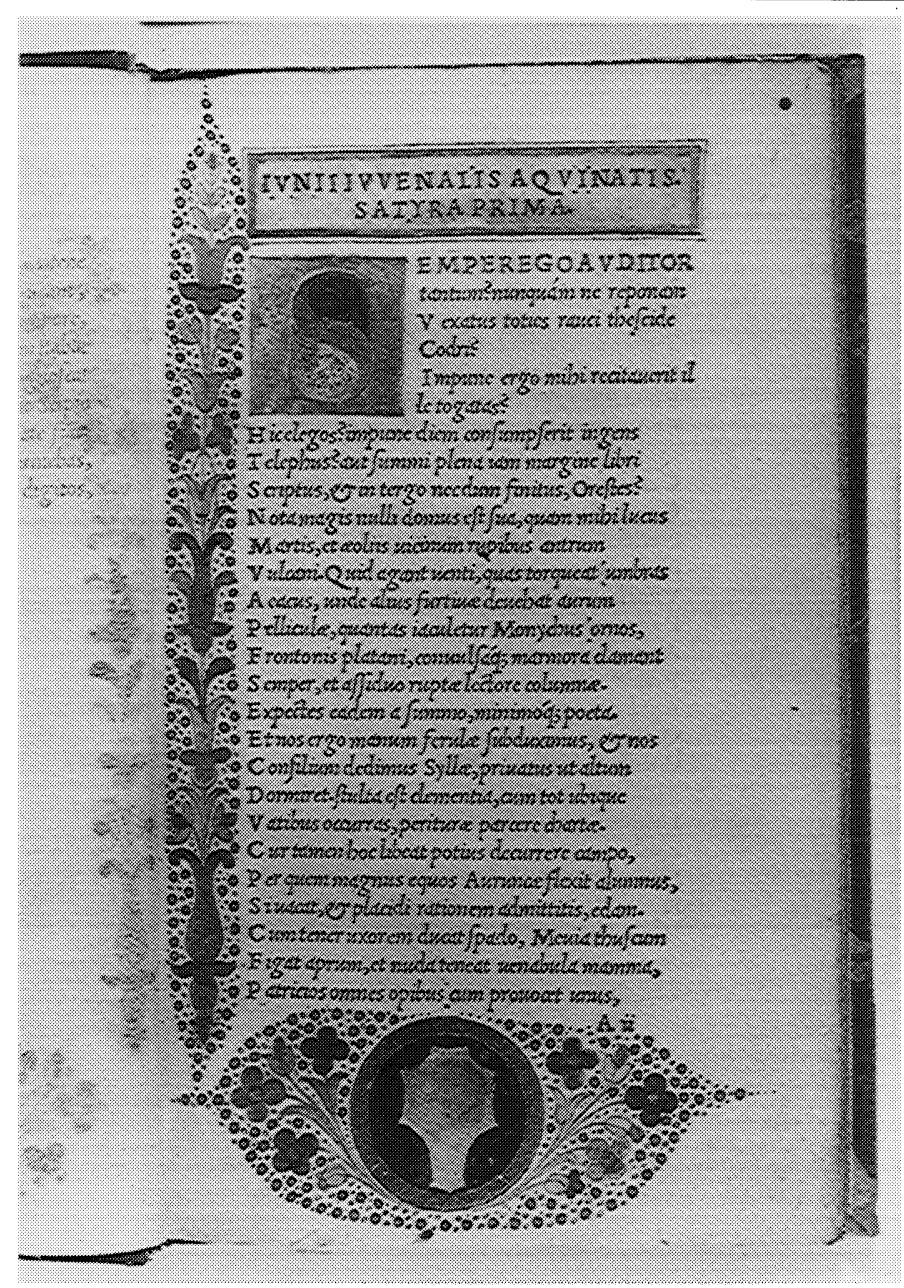

3. Illuminated opening page of a copy of the third Lyonese Juvenal-Persius (c. I 504). (Reproduced by courtesy of the Director and University Librarian, The John Rylands University Library of Manchester. Shelf-mark: Christie 34, fol. I 8 . Leaf size I 64 X $98 \mathrm{~mm}$.) 


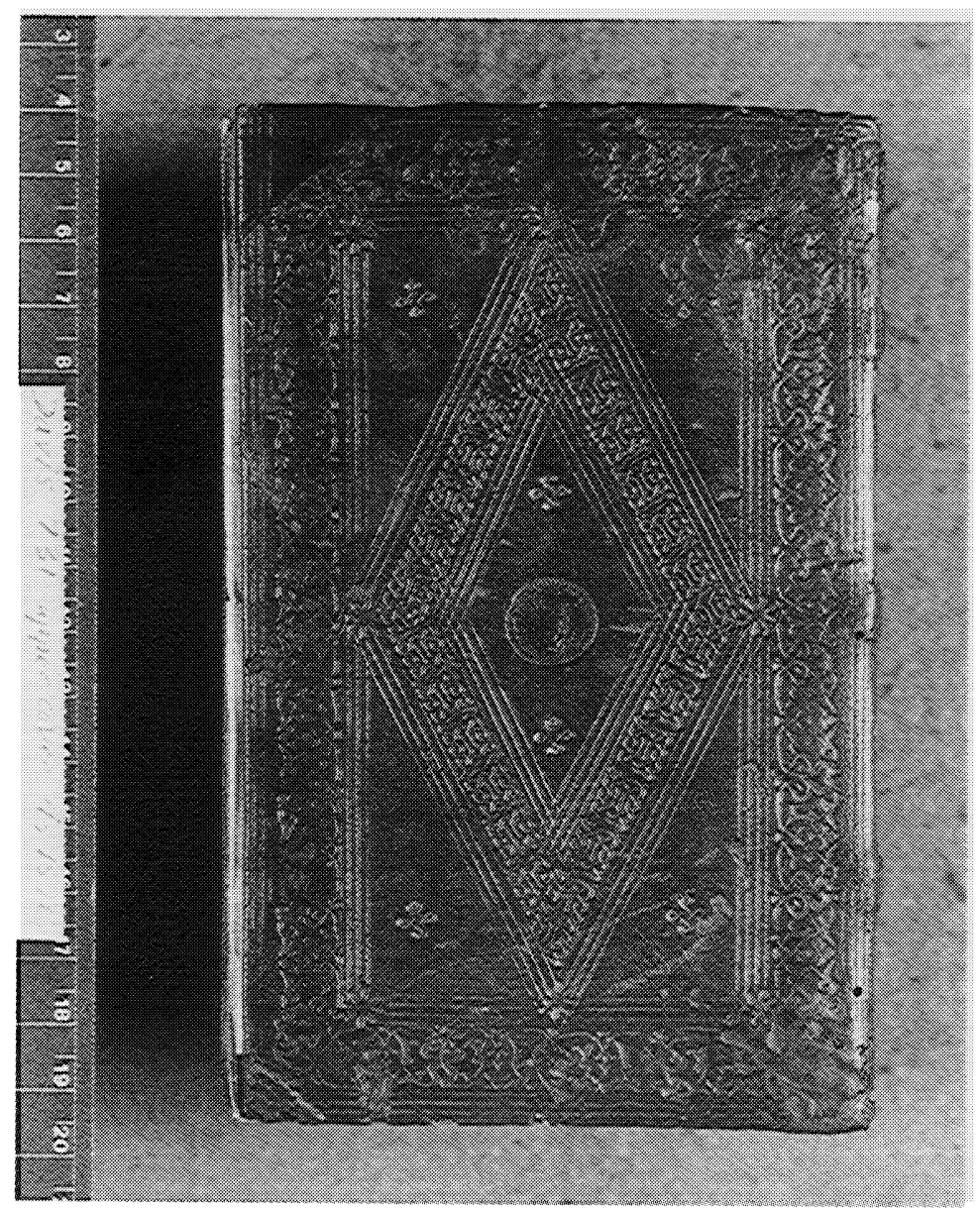

4. Lower cover of an Italian medallion binding, Rome c. I 5 I5, on a copy of the first Lyonese edition of Lucan (c. 1503).

(Reproduced by permission of The British Library. Davis 73 I. 155 x $100 \mathrm{~mm}$.) 
leaf work on a specked background appears to be typical of Venetian illumination. Examples can be found in the 1994 Florence catalogue as well as in an illuminated copy of the 150 r Aldine Juvenal-Persius now in the Library of the University of Texas, Austin. ${ }^{22}$

Secondly, I have seen occasional references to or descriptions of Italian bindings on early Lyonese italic-letter editions. Since I know of little work on this question, I think it would be useful to present as complete a list as possible of the copies that appear to have fairly contemporary Italian bindings. ${ }^{23}$ It should be noted that most of these are editions of works that are not in Italian (as opposed to the editions of Dante and of Petrarch).

I. A Roman (or perhaps Venetian) medallion binding on a copy of the first Lyonese edition of Lucan (c. I 502): London, The British Library, Davis 73 I (see fig. 4). This binding has been dated c. I 5 I 5 but it could have been executed earlier. ${ }^{24}$

2. A Roman medallion binding with a cameo of Julius Caesar (about $40 \mathrm{~mm}$. across) on the c. 1504 edition of Philostratus: London, The British Library, Davis 723 (formerly P.1 235).

3. A Roman medallion binding with remains of gold-tooling showing the figure of Julius Caesar (same as previous) on the c. I 504 edition of Philostratus: Rome, Biblioteca Nazionale Centrale Vittorio Emanuele, 7r.9.a.25. These two bindings have been dated c. 15 10-25 by Anthony Hobson. ${ }^{25}$ (See fig. 5 )

4. A binding with gold-tooled knotwork and a linked arabesque ornamental border containing the name 'Prudentius' in the centre panel on both covers, which de Marinis has assigned to Rome: Milan, Biblioteca Trivulziana, Triv. L $1624 .{ }^{26}$ (see fig. 6)

5. A gold-tooled Roman binding c. I5 10-20 with elaborate floral and linked arabesque decoration on the 1508 edition of Cicero's Orationes: Los Angeles, University of California Library, Department of Special Collections $125243 .{ }^{27}$

6. A heavily worn, medallion binding with interlaced vine-work, which de Marinis has classed as Venetian, on a copy of the c. I 504 Prudence et al.: Bologna, Biblioteca dell'Archiginnasio, I6.c.V.82. ${ }^{28}$

7. A binding with blind-stamped decoration which de Marinis has assigned to Venice on a copy of Aristotle, De natura animalium (c. I 506): Palermo, Biblioteca communale, Esp.XII.E.26.8. ${ }^{29}$

8. A binding (well-restored) which can be assigned to Naples on a copy of Vol. I of the I 5 Io Lyonese edition of Pliny's Historiae naturalis: Oxford, Bodleian Library, Broxb. ro. I3. 
9. Finally, an interesting inscription in a copy of the c. I 503 Dante has been noted: it indicated that the volume had been purchased in Rome in December 1515 by the bibliophile Fernando Colón. Although this book ended up in Leipzig, where it was destroyed during World War II, de Marinis was able to provide a picture of one of the covers of the binding, which he claimed was done in Venice. ${ }^{30}$

More bindings must be examined, and more carefully, especially in Italian libraries, where I have not had the opportunity to work. It is to be hoped that it will eventually be possible to date some of them with more accuracy. But I believe we can say tentatively that existing evidence does point to the diffusion of the early Lyonese pseudo-and quasi-Aldines in Italy, and not just the editions of Dante and Petrarch in Italian. For the time being, the city of Rome seems to show up more often, but we should not exclude Venice, in spite of Aldus's multiple privileges. We should also be on the look-out for copies from Milan and the Milanais, which was under French control between 1498 and 1512 and again from I 515 to 1524 .

Now, let us see what we can find out about the diffusion of the italic-letter pseudo- and quasi-Aldines in France. To begin with, there exists one early Lyonese pseudo-Aldine with an illustrious pedigree: the earliest book known to have belonged to Jean Grolier is a copy of the first Lyonese edition of Catullus-Tibullus-Propertius. A manuscript note once read: 'Cest a Jean grolier, de Lyon.' At the end of the volume is a second manuscript note which reads: 'Pro Johanne Grolier Lugdunen. ${ }^{31}$ Anthony Hobson has suggested that the presentation formula might be in the hand of Gaspar [Mazzoli] d'Argile of Bologna, one of Grolier's teachers during his college days in Paris, whom he had hired as a private tutor in classical studies in 1508.32

This binding shares many traits with a group of early I 6th-century bindings known as 'reliures Louis xII.' Their most significant characteristic is that they represent the earliest bindings executed in France which show Italian-style gold-tooling (see fig. 7). Every one of the stamps used on these covers shows up on other bindings of the group. ${ }^{33}$ Although it was originally projected that this group of bindings was from a shop in Blois or at court, it has since been argued that it is much more likely that it is Parisian. ${ }^{34}$ The current consensus is that the shop belonged to Simon Vostre. Grolier's binding has been dated c. 1503 and c. I5I4 (and even c. 1520). Assuming with Dacier that Grolier would not have ordered such a binding 


\section{Counterfeit Aldines and Italic-Letter Editions Printed in Lyons}

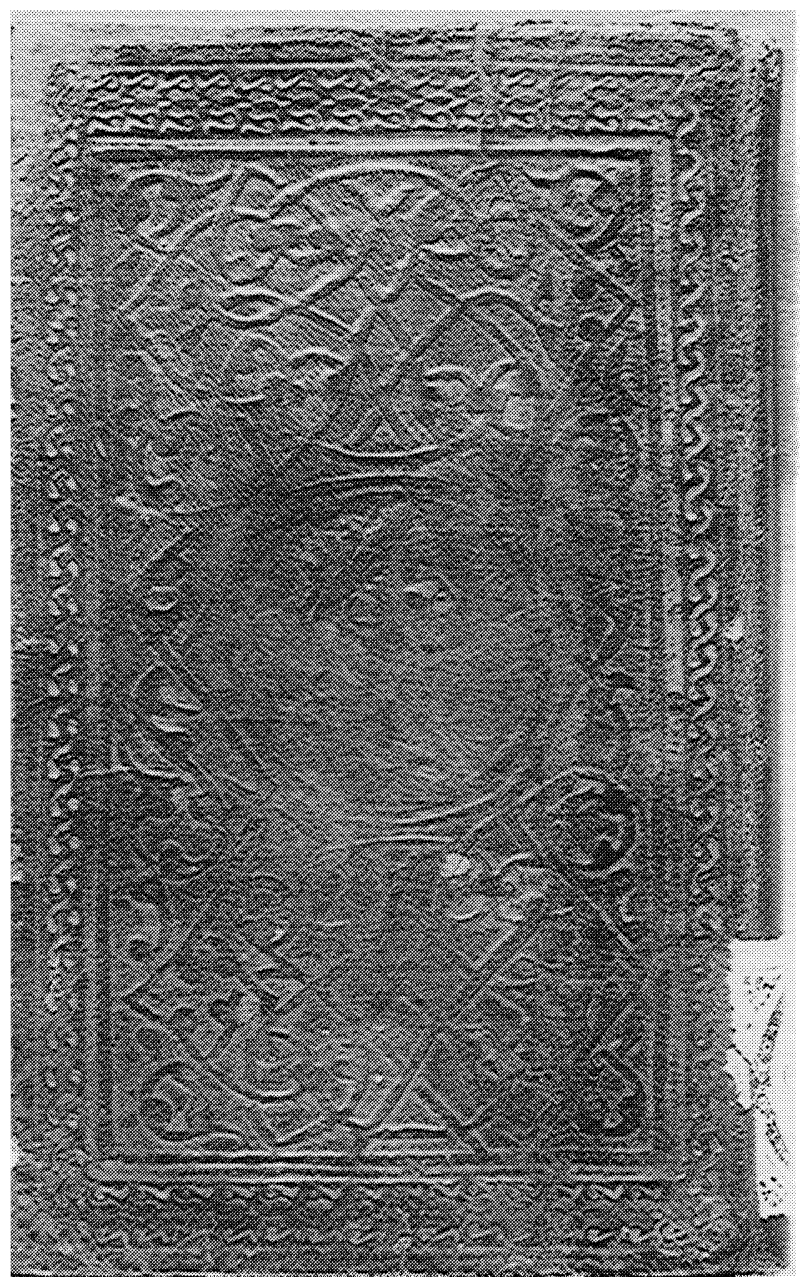

5. Lower cover of a medallion binding with remains of gold-tooling on a copy of the Lyonese Philostratus (c. I 504). (Reproduced by permission of the Biblioteca Nazionale Centrale Vittorio Emanuele, Rome. Shelf-mark: 71.9.a.25. I63 x 96 mm.) 


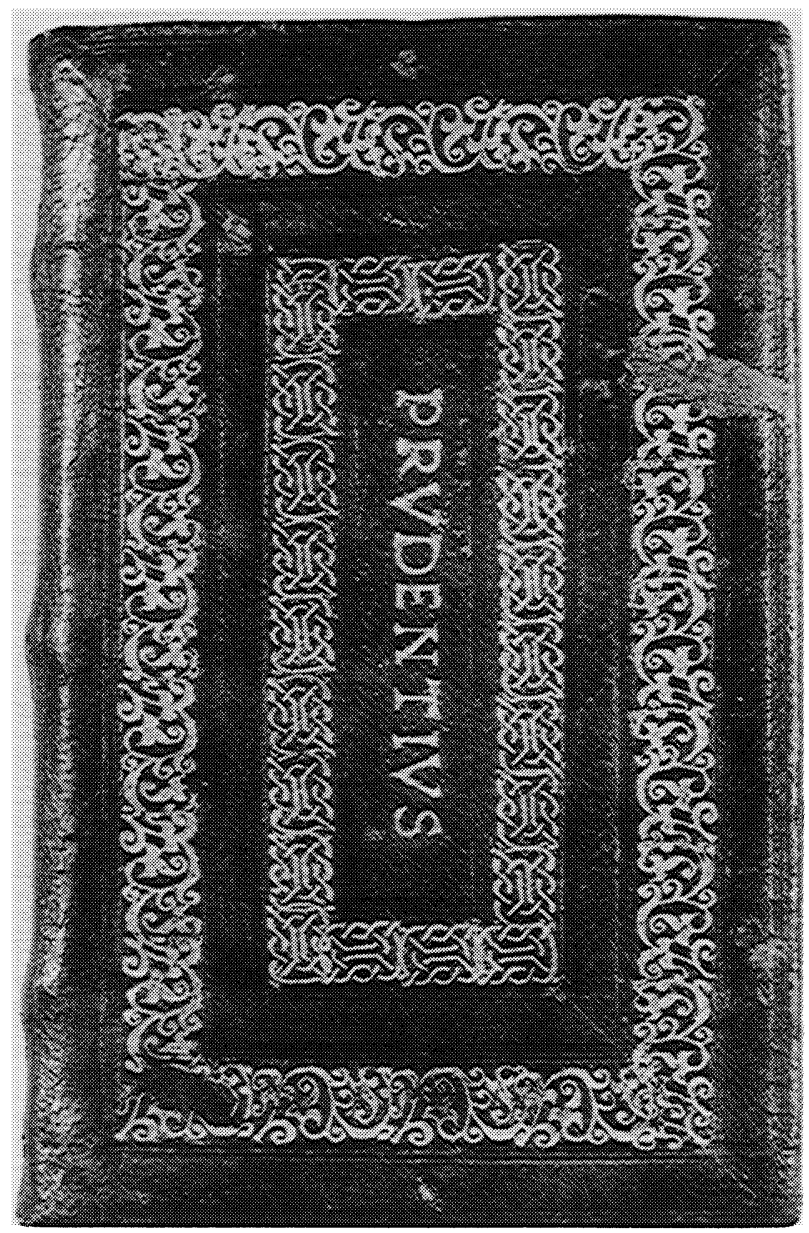

6. Upper cover of a gold-tooled binding on a copy of the Lyonese edition of Prudentius et al. (c. I 504). (Reproduced by permission of the Biblioteca Trivulziana, Milan. Shelf-mark: Triv. L I624. I65 x $105 \mathrm{~mm}$.) 
after his return from Italy, this implies that it must be prior to September 1509, when Grolier appeared in the duchy of Milan as 'trésorier et receveur des finances.' Argile taught in Bologna in I 505-06, but we also know from the preface to the 1508 Lyonese edition of Suetonius that Grolier had previously been Argile's student in Paris and, as was the custom, had lived in his house. ${ }^{35}$ This binding almost certainly dates from Grolier's years as a student in Paris. Hobson has dated it c. 1507, making it the earliest known Parisian binding on a Lyonese italic-letter imprint. ${ }^{36}$

Next, let us examine the pseudo-Aldines that were published in France. To begin, the same Gaspar d'Argile prepared an italic-letter edition of Suetonius. For once, these volumes bear a colophon, dated 3 October $1508 .{ }^{37}$ In addition, on the verso of the title-page, this edition contains a dedicatory epistle to his student, Jean Grolier, recently named 'secretary to the most Christian King of France' (see fig. 8). The epistle clearly states the intended audience for this edition of Suetonius, since the lives contain 'lessons that princes must follow to administer well, as well as examples of acts which, by reading, they will know how to avoid. ${ }^{\prime 38}$ In an article devoted specifically to this edition, Saffrey has underlined the extent to which the printer de Gabiano was unable to assure a competent reading of the manuscript of the Latin epistle which had been given to him (and thus would have been unable to produce a decent Latin edition). ${ }^{39}$ It should be noted, however, that whatever his shortcomings may have been, Argile chose to submit his text to de Gabiano, that is to the printer he described as 'Balthasari calcographo Lugdunensi elegantissimo.' I think this is sufficient evidence to conclude that, at least among the educated Italophiles, such italic-letter editions were well looked upon at the time. If, originally, the idea had been to compete with Aldus and the Giunti in the major Italian centres, the success of the octavo Aldines would have made it increasingly interesting to create or develop a market in France for such volumes.

As his copy text, Gaspar d'Argile could have taken any one of twenty-odd editions of Suetonius which were published in Italy between 1470 and $1506.4^{\circ} \mathrm{All}$ but one of these (a quatro) were folios and, from I 488 , all of them contained commentary, whether by Beroaldo or Sabellico, or both. ${ }^{41}$ The 1508 Lyonese edition was the first edition to appear in print north of the Alps. And it had all of the Aldine characteristics: it was the first edition of Suetonius in italic, the first without commentary since the earliest editions, and the first to be printed 'ad Enchyridii formam,' as Argile specified 
in his epistle..$^{2}$ Given the subject-matter, such a volume would naturally appeal to the princes and administrators that Argile specifically mentions in his preface, as well as to students. The young Grolier was at once a student participating in this exercise (he and Argile had read Suetonius together) and also the type of administrator who, it was projected, would profit from its lessons.

There also exists an edition of Quintilian printed in a Lyonese italic from the year $15 \mathrm{IO}$. The text was prepared by another Italophile, Geofroy Tory, regent at the Collège du Plessis in Paris. In the dedicatory epistle, he claimed to have taken pains to collate several manuscripts. ${ }^{43}$ The edition was dedicated to Jean Rousselet, seigneur de la Part-Dieu near Lyons. Rousselet was, in fact, of Italian origin (Ruccelli). A great lover of letters ('literarum amantis$\left.\operatorname{sim}[u s]^{\prime}\right), 44$ he was married to Jeanne Lallemant, daughter of Jean senior, a close friend and patron of Tory from his native Bourges. ${ }^{45}$ According to the brief epistle, it was Rousselet who had enjoined Tory to undertake this work and to have it handsomely ('bellissime') printed in Lyons. ${ }^{46}$ Such a preface provides further evidence of the estime which Aldine-style, italic-letter octavos were accorded in some circles in Paris and in Lyons by this date.

The editor, Tory, taught in Paris; in addition, two of the remaining copies of this edition (I have knowledge of eleven) bear contemporary Parisian panel-stamp bindings. The Bibliothèque municipale de la Ville de Lyon holds a beautifully preserved copy in a brown leather binding with a St. Sebastian and St. Barbara stamp on each cover, around which runs the motto and name: ${ }^{\star}$ * TOVT SE PASSE * FORS * AYMER DIEU * Julien des Jardins *.'47 The second one is housed in the Bibliothèque publique et universitaire in Geneva. Both covers show the well-known 'Sainct yues' stamp belonging to Des Jardins. ${ }^{{ }^{8}}$ Although less well-preserved, the Geneva binding has been easier to photograph (see fig. 9).49 The 'Sainct yues' panel is also found on a copy of the 15 Io Lyonese italic-letter edition of Historia ex Trogo Pompeio by Justinus. ${ }^{\circ}$ More clear-cut than the Grolier Catullus, the existence of three panel-stamp bindings from the shop of Julien des Jardins on volumes printed in Lyons in 1510 provides, I think, solid evidence that these books were being sold in Paris by the early 15 IOs. ${ }^{51}$

There is one final instance which poses some problems but which may eventually be of use in this discussion. What appears to be a Paris panel-stamp binding covers a copy of one of the two early quasi-Aldine editions of Sallust produced by the Lyonese..$^{52}$ The first one by date appears to be Thomas Murchius's edition of Sallust, the 
89 Counterfeit Aldines and Italic-Letter Editions Printed in Lyons

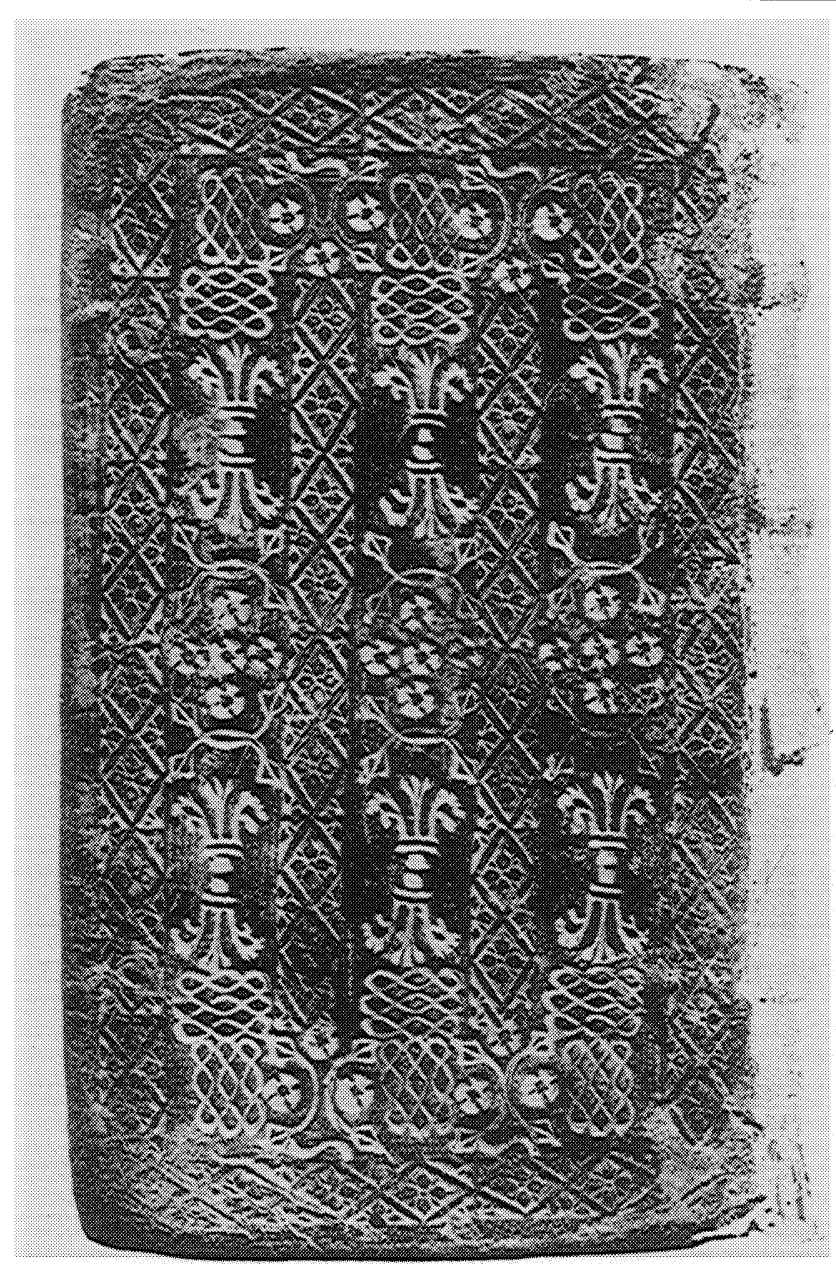

7. Lower cover of the 'Louis XII' binding on Grolier's copy of the first Lyonese edition of Catullus-Tibullus-Propertius (c. I 502). (Photograph of the illustration in Les Trésors des Bibliothèques de France, Vol. v, Plate III. Cover size 165 x $100 \mathrm{~mm}$.) 


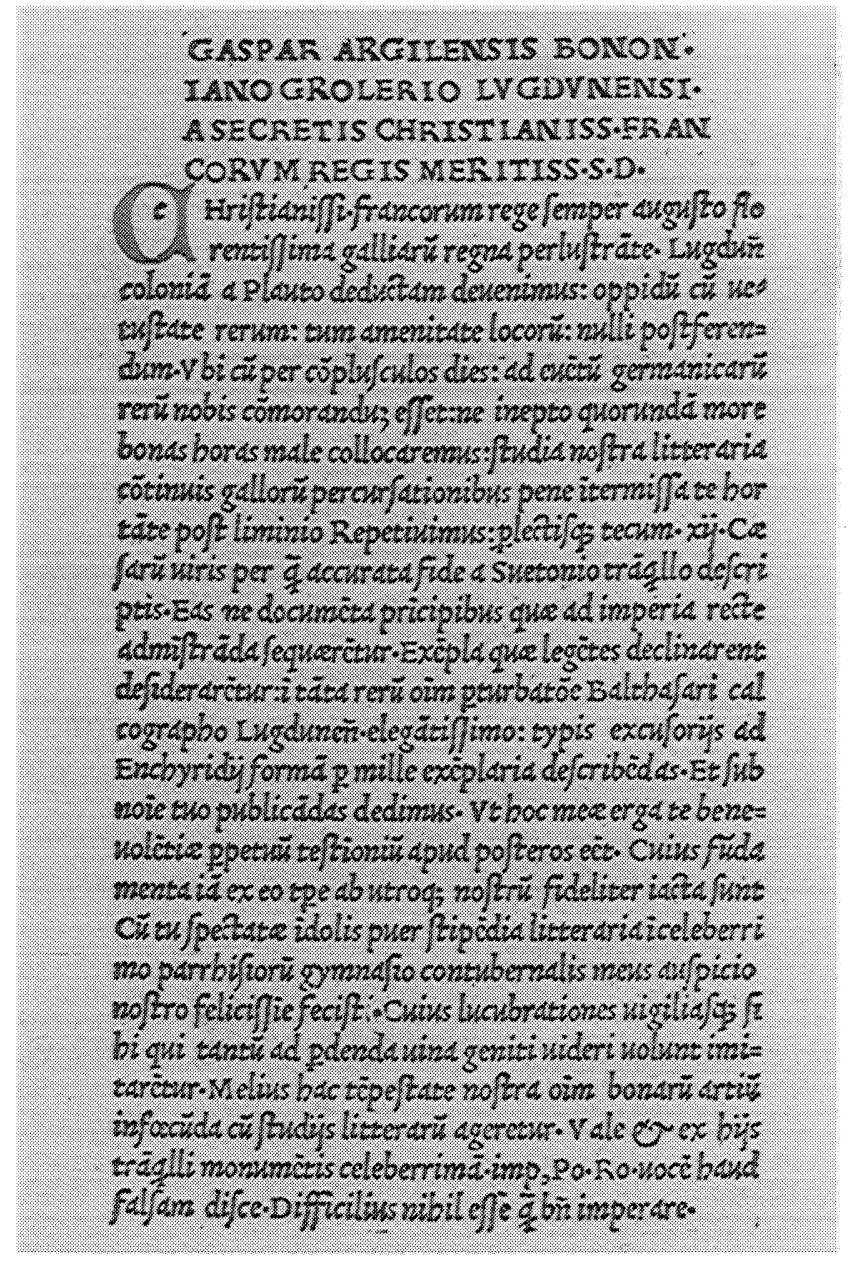

8. Verso of the title containing dedicatory epistle from Gaspar Argilensis to Jean Grolier in Suetonius,

De Vita.xii. Caesarum, Lyons, October 3, 1508.

Contemporary roulette binding with two painted initials.

(Reproduced by permission of the Department of Rare Books and Special Collections, McGill University Libraries.

Call number: Y35.S8c.I 508* . Leaf size $167 \times 100 \mathrm{~mm}$.) 


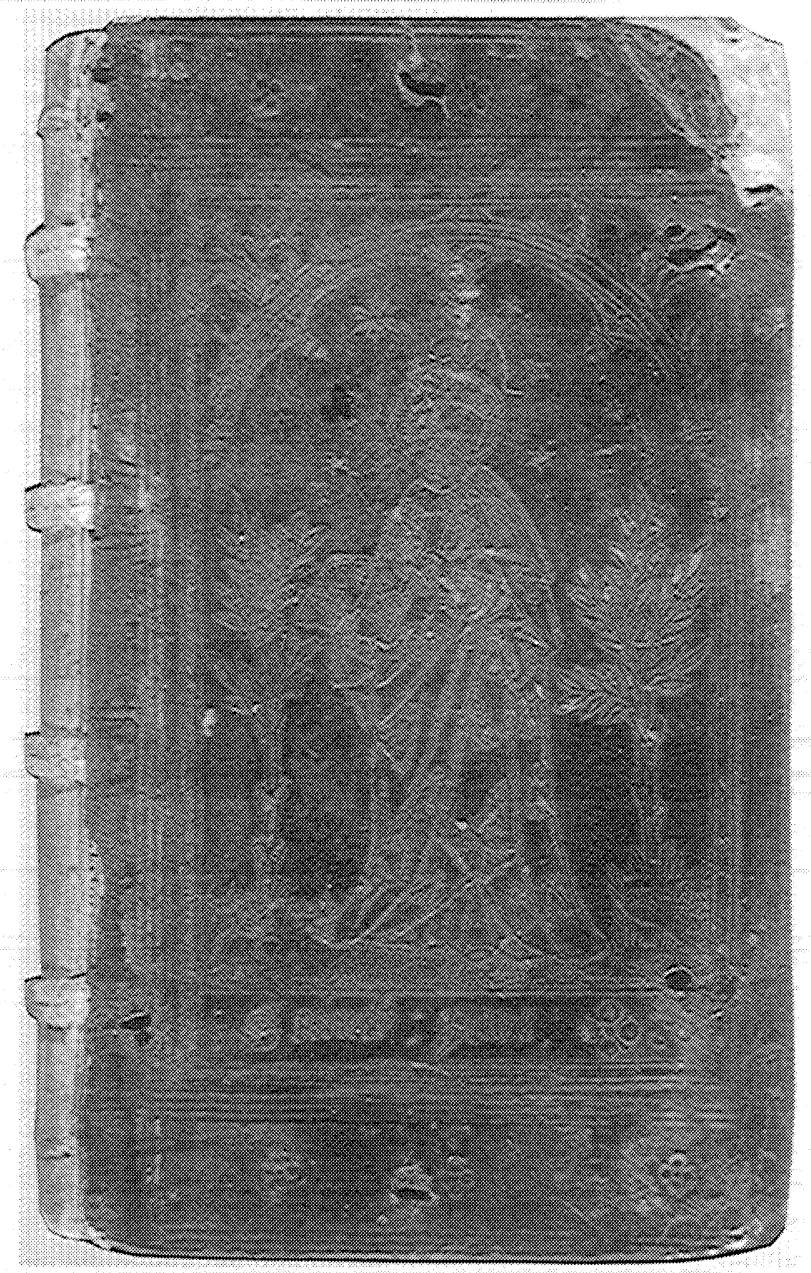

9. Upper cover showing St. Yves panel-stamp of Julien des Jardins on a copy of the Tory edition of Quintilian (I 5 I O).

(Reproduced by permission of the Bibliothèque publique et universitaire, Université de Genève. Shelf mark: Ha 642 Rés. Cover size 172 X 96 mm.) 
preface of which was signed in Blois on 2 June 1504 . But according to Baudrier, this edition is based on the Lyonese edition by B. Fidelis with a preface dated 5 November 1504 (which, in turn, appears to reproduce the text of the italic-letter edition published by the Giunti in Florence in January I 504). To have two different editions of Sallust in italic from Lyons within half a year seems to me a bit surprising. This might suggest rivalry between several of the participants in the Lyonese italic adventure, but I do not know of any other such indications. ${ }^{53}$ If we accept Baudrier's opinion that the Murchius edition is derived from the Fidelis edition, one way to set the situation straight would be to assume that the date was incorrectly composed. If, once again, we presuppose that the Lyonese kept up with events in Venice, it would be unlikely that Murchius's edition was later than 1509, when the Aldine Sallust appeared (and it was copied by the fleur-de-lys printer c. I 5 Io). If so, we might look at possible errors in the date: a missing or miscomposed ' $\mathrm{v}$ ' could lead to a reading of 1507 ('vii') or I 508 ('viii').54 The binding could thus be dated 1508 or slightly later. But there are many unknowns in this particular case. 55

In brief, evidence from the bindings suggests that it was roughly during the years $15 I^{10}-12$ that the Lyonese italic-letter editions gained a firm foothold in the Paris market. ${ }^{56}$ There is, however, one detail that would seem to go against such an interpretation: it has generally been accepted that the earliest Parisian italic font was being used by Guillaume Le Rouge by about I 507.57 It might appear that Le Rouge was attempting to react as best he could to the success of the various southern italics, Aldine, Lyonese, Giuntine, etc. He may well have been trying to be the first Parisian printer to follow the new style. If, however, he already had such a font by I 507, I would have to revise my tentative chronology. In fact, according to the analyses of Brigitte Moreau, Le Rouge's italic-letter imprints of classical texts must be dated to the years I 5 II $-I_{3}$, precisely the years indicated by the bindings that have come to light, and which correspond to the beginning of the Trot's fleur-de-lys period..$^{8}$

There is one further point concerning the early Lyonese italic editions and their diffusion which should be noted. It appears that as many as twenty copies printed on vellum have survived of editions dating from about I 503 to about I 507 or I 508, that is, after Aldus's 'Monitum' and before the fleur-de-lys stage ( $15 \mathrm{ro}$ ). This is by far the most productive period of the Lyonese Aldine imprints. It must be remarked here that vellum copies of any publication were not common in Lyons during these years, and vellum copies of 
octavos even less so. In the case of the second edition of Juvenal/ Persius (c. 1 503), the first of Cicero's Opera (c. I 506) and of Philostratus (c. 1 504), three vellum copies are known. ${ }^{59}$ Two such copies are known of the earliest edition of Dante (c. 1503; no copy of the supposed second edition has yet been identified), of Cicero's Epististolae familiares (c. I 506), and of the second Petrarch (c. I 508, but perhaps earlier)..$^{60}$ Single vellum copies are known or have been cited for the first Valerius Maximus (c. 1 503), the second Juvenal/ Persius (c. I 504), the second Virgil (c. I 504), and a Horae (c. I 505).$^{6 I}$ It would, of course, eventually be useful to know where, and perhaps even for whom these copies were produced. For certain individuals? For the Northern Italian market? The titles of some of them have been painted over or redone in gold lettering. ${ }^{62}$ But from our current standpoint, the essential fact is that they exist, thus indicating the presence of both an offer and some demand for such copies. ${ }^{63}$ This is one further testimony to the prestige which the new Aldine-style octavos had acquired during the first decade of the I6th century. The best, from all points of view, generally came from the press of Aldus and Torressani, but there were also the Giunti in Florence and Socino in Fano. The Lyonese may have been sloppy in their typesetting, they probably had no proofreaders, their paper may not have been of the highest quality, their type did not contain all the ligatures that Aldus thought were appropriate; but all available evidence shows that they were still able to participate in and profit from this new trend in the publishing world, and that, in all likelihood, they had some impact on the spread of the Aldine book to Paris and perhaps other cities north of the Alps. ${ }^{64}$

In I 803, after years of work, Renouard was able to write: 65

Pour en revenir à nos Lyonnois, [ . . ] ils vouloient que leurs volumes sans date fussent confondus avec les éditions Aldines, et c'est ce qui, pendant trois siècles, est presque toujours arrivé. Ce n'est que depuis la découverte de l'Avis imprimé par Alde en 1503 [et réédité en 1790] qu'enfin on a cherché à distinguer ces éditions lyonnoises que jusqu'alors, même les bibliographes les plus instruits, avoient presque toujours annoncées comme imprimées par les Alde ou par les Giunti.

Renouard rightly started the movement to separate the true Aldines from the false. Although Lyonese Aldines are still considered an ancillary part of many Aldine collections, ${ }^{66}$ there is no doubt that these imprints have suffered considerably from being classed as 
counterfeits. I have tried to show that, from an historical perspective, we must look not just at Aldus's views, or even Renouard's, but above all at how these volumes were received, and how they were valued by their earliest possessors. From this perspective, we are led to conclude that the Lyonese italic-letter editions, while well below the Aldine standard on most counts, must be viewed as an integral part of the overall Aldine phenomenon during the early years of the 16 th century.

\section{RESUME}

Cette communication présente un examen détaillé des éditions d'Aldus contrefaites à Lyons au début du seizième siècle. Ces livres copièrent le format in-octavo d'Aldus et son caractère italique, et souvent aussi ses textes. Des indices, provenant surtout de l'examen des reliures, sont présentés pour déterminer les points de vente de ces éditions. Cela permet également de démontrer qu'elles étaient très prisées et n'étaient pas simplement considérées comme de vulgaires copies des éditions aldines originales. 


\section{NOTES}

Earlier and more wide-ranging versions of this paper were given at the McGill Aldine conference on 25 October 1995, as well as at the École Nationale Supérieure des Sciences de l'Information et des Bibliothèques (ENSSIB) in Lyons/ Villeurbanne on 24 June 1996. I wish especially to thank all the librarians and curators who made it possible for me to examine a large number of these volumes, often in a short amount of time (see note 18 for the list of the principal collections examined).

I The text of these privileges is given in $\mathrm{H}$. George Fletcher, New Aldine Studies (San Francisco: B.M. Rosenthal, 1988), I43-7, I 5 I-2: 'Senatorial Ten-Year Privilege for Italic Type and Seven Greek and Latin Authors' (23 March I 501 ); 'Dogal Ten-Year Decree against Counterfeiters' (I4 November I502); 'Papal Privilege' from Alexander vi against the counterfeiters ( 17 December I 502).

2 Basic work on the identity of the Lyonese printers has been done by AntoineAugustin Renouard, Annales de l'imprimerie des Alde, 3rd ed., (Paris: Jules Renouard, I 834); J. et H. Baudrier, Bibliographie Lyonnaise, Vols. viI-viII (Lyons and Paris: L. Brun and A. Picard, 1908-10); David Shaw, 'The Lyons Counterfeit of Aldus's Italic Type: A New Chronology,' in Denis V. Reidy, ed., The Italian Book I465-I 800 (London: British Library, 1993), I 1 7-33; and Nicolas Barker et al., eds., A Catalogue of the Ahmanson-Murphy Aldine Collection at UCLA. Fasc. V. The Publications of the Torresani, Contrefactions, Associated Material, $\Theta$ Addenda (Los Angeles: Department of Special Collections, University Research Library, UCLA, 1994) (=CAMAC V). See also the 1976 catalogue of the Parisian bookseller, Georges Heilbrun, entitled 'Le premier caractère italique en France.'

3 The unique original copy from the Bibliothèque nationale de France (Ms. Gr. 3064 , fo 85 ) is reproduced in L. Bigliazzi et al., ed., Aldo Manuzio tipografo 1494-I 5 Is (Florence: Octavo, 1994), I 16; and in Fletcher, New Aldine Studies, 52; text given in Renouard, Annales, $32 \mathrm{I}-3$. In the sixth line, Aldus saw the Lyonese as conspiring against him ('in me conspiratum est'), goaded by the ever-present Avaritia.

4 For an inventory and analysis of the large number of ligatures, see the 'Appendix on Italic' in Nicolas Barker's Aldus Manutius and the Development of Greek Script and Type in the Fifteenth Century, 2nd ed. (New York: Fordham University Press, 1992/, 109-1 8 and 132 . The Lyonese types only reproduced the most common of these, as Aldus underlined.

5 Renouard, Annales, 305-7, nos I, 2, 3, 4, 6, 7, and Io.

6 A complete list of Aldine imprints for the years $1501-1503$ can be found on pp. 144-5 of Martin Lowry's Aldus Manutius: Business and Scholarship in Renaissance Venice (Oxford: Blackwell, 1979). A Lyonese edition of Cicero's Epistolae familiares is traditionally dated c. I506.

7 See also Shaw, 'The Lyons Counterfeit,' 120.

8 Complete copies are held at Yale (Gnv60.A50IB) and at Princeton (VRG 2945.I501.II). The copy Baudrier cited at the Musée Calvet (now part of the Bibliothèque municipale/ in Avignon is missing. The Rylands Library holds a 
copy of the Bucolica (Christie $34 \mathrm{~g} 2 \mathrm{I}$ ). In addition to Baudrier, the Lyonese italics have been described and some new copies noted in Sybille von Gültlingen, Bibliographie des livres imprimés à Lyons au XVI ${ }^{e}$ siècle, 3 vols. published to date (Baden-Baden and Bouxwiller: Valentin Koerner, I992-5), I: 63-70 (Balthazard I de Gabiano), II: I05-I 2 (Barthélemy Trot).

9 Although the first leaf of this copy was inadvertently folded during printing, it is possible to reconstruct the title: PVBLI[I TEREN]TII / / CO[MED]IE. The final 'TII' and 'IE' are visible in the left border of the verso of the title-page (see fig. 2).

Io Following George Fletcher, I think it would be useful to distinguish the two cases, that is, the copying of an Aldine edition and its type as opposed to the use of the Aldine formula (octavo edition without commentary, in italic type/ to print other works. In the first case, which in the early years was the most common, we can speak of counterfeits, or 'pseudo-Aldines;' in the second, the term 'quasi-Aldines' is certainly a constructive suggestion. (H. George Fletcher, In Praise of Aldus Manutius: A Quincentary Exhibition (New York: The Pierpont Morgan Library; Los Angeles: Department of Special Collections, University of California, Los Angeles, 1995/, 55 and I27-8.)

I I The earliest Lyonese reprint of Lucan, mentioned in the 'Monitum,' also shows an interesting trait: in this one instance, the Lyonese did not reproduce Aldus's preface but substituted a six-line 'Lucani epithaphium.' This might suggest a difference of opinion concerning this particular aspect of their operation. However, if it existed, such hesitation was not long-lasting.

I2 The question of the identity of the italic types and the printers, originally discussed by Renouard and by Baudrier, has been reanalysed recently by Shaw ('The Lyons Counterfeit'), as well as by Nicolas Barker in the Introduction to CAMAC V (xii-xvii).

I 3 In two cases (Aristotle and Prudentius), the Lyonese printed Aldine-style octavo editions of texts published by Aldus in roman-letter and in larger formats.

14 A.F. Johnson, Type Designs, Their History and Development, 3rd ed. (London: Andre Deutsch, 1966), 97; Alberto Tinto, Il corsivo nella tipografia del Cinquecento: Dai caratteri italiani ai modelli germanici e francesi (Milan: Il Polifilo, 1972), 32-3. I will return to this matter below.

I5 Johnson, Type Designs, 98-9.

I 6 'Balthasari calcographo Lugdunensi': see Renouard, Annales, 309, n' 271 ; Baudrier, Bibliographie Lyonnaise viI, 23; Shaw, 'The Lyonese Counterfeit,' $\mathrm{n}^{\circ} 29$.

17 Fleur-de-lys printed in red are found on title-pages of the dated 15 ro editions of Justinus and Quintilian. For a reproduction, see the title-page of the 1512 Xenophon given as Plate II in CAMAC V. (The accompanying initials S.V. would normally, in a Lyonese imprint, lead us to Simon Vincent, or a member of his family. If so, this would provide us with the name of an important secondary (?) distributor of these volumes.)

I 8 In preparing this paper, I have examined most or all of the copies at the following libraries: CANADA: Montreal, Department of Rare Books and Special Collections, McGill University Libraries. USA: Cambridge (MA), Houghton Library, Harvard University; New Haven (CT), Beinecke Library, Yale University; New York (NY), 
Butler Library, Columbia University; The Pierpont Morgan Library; The New York Public Library. england: Cambridge, University Library; Trinity College Library; London, The British Library; Manchester, The John Rylands University Library; Oxford, The Bodleian Library. BeLgrum: Brussels, Bibliothèque Royale Albert rer. FRANCE: Lyon, Bibliothèque municipale; Paris, Bibliothèque nationale de France. switzerLAND: Genève, Bibliothèque publique et universitaire.

I9 See Jonathan J.G. Alexander, ed., The Painted Page: Italian Renaissance Book Illumination I450-Is5o (Munich and New York: Prestel, 1994).

20 See Angela Dillon Bussi, 'Le Aldine miniate della Biblioteca Medicea Laurenziana,' in Bigliazza, Aldo Manuzio typografo, 20I-28; Helena Szépe, 'The Book as Companion, the Author as Friend: Aldine Octavos Illuminated by Benedetto Bordon,' Word थ Image II, I (r995): 77-99; and the section on 'Hand-Illuminated Aldines: A Coda' at the end of Lilian Armstrong's chapter on 'The Hand-Illumination of Printed Books' in Alexander, ed., The Painted Page, 46-7.

2I Shelf mark: Christie $34 \mathrm{f}$ i 8 . The initial page of Persius has a smaller illuminated border in the same style. The volume also contains eleven gold initials measuring $7 \mathrm{~mm}^{2}$; nine measuring $9 \mathrm{~mm}^{2}$; and one measuring I I $\mathrm{mm}^{2}$ /at the beginning of Persius).

22 Bussi, 'Le Aldine miniate,' 215 and 2 18; Christie's catalogue of 24 March I97 I, lot 15 (and illustration). The latter copy is now in the Library of the University of Texas, Austin (call number: Uzielli 38). I wish to thank Helena Szépe for telling me about this particular illuminated opening page and the description in the 197 I Christie's catalogue.

23 The only statement I know of in this regard is to be found on p. 55 of the recent Aldine catalogue prepared by H. George Fletcher, In Praise: 'We should also note that because so many copies of these piracies are still found in contemporary Italian bindings, the Lyonese must have sold into the Italian market deliberately, and this tactic must have been part of their agenda from the beginning.' In the following descriptions, both for reasons of space as well as competence, I will eschew detailed descriptions of material and colour.

24 At The British Library, I wish to thank Philippa Marks for giving me access to the notes on this volume made by Mirjam Foot, for looking after the delicate task of photographing this binding, and for consultations concerning several other bindings.

25 Hobson, Humanists and Bookbinders: The Origin and Diffusion of the Humanist Bookbinding 1459-1559 (Cambridge: Cambridge University Press, 1989), $22 \mathrm{I}, \mathrm{n}^{\circ} \mathrm{I} 5 \mathrm{k}$ and $\mathrm{l}$.

26 Tammaro de Marinis, La legatura artistica in Italia nei secoli xve xvI (Florence: Fratelli Alinari), 1960, I: $\mathrm{n}^{\circ}$ 445. I would like to thank Dott. Giovanni M. Piazza of the Biblioteca Trivulziana for information on this binding.

27 CAMAC V (see above note 2 ) $74-5, \mathrm{n}^{\circ} 76 \mathrm{r}$ and Plate $\mathrm{xv}$.

28 de Marinis, La legatura artistica, $\mathrm{II}: \mathrm{n}^{\circ} \mathrm{I} 68 \mathrm{I}$ bis.

29 Ibid., III: $\mathrm{n}^{\circ} 3$ I 13.

30 Ibid., II: $\mathrm{n}^{\circ} \mathrm{I744}$ and Plate cccxxxIII. Colon's presence there at that time is 
confirmed by the entries in Klaus Wagner and Manuel Carrera, Catalogo dei libri a stampa in lingua italiana della Biblioteca Colombina di Siviglia (Modena: Panini, 1991).

3 I See, in particular, Jacques Guignard, 'Notes et hypothèses à propos de Jean Grolier et des débuts de sa collection. 1503-1515,' in Festschrift Ernst Kyriss. (Stuttgart: Max Hetter, 196I), pp. 19I-225. See also Émile Dacier, 'L'atelier des “reliures Louis XII". Les premières reliures françaises à décor doré,' in Les Trésors des Bibliothèques de France, Vol. v, fasc. xvir (Paris: Éditions d'art et $\mathrm{d}^{\prime}$ histoire, I935), 8-40, $\mathrm{n}^{\circ}$ I (Planche III).

32 Humanists and Bookbinders, I $14-16$. According to Hobson, Grolier would have been in his early twenties in 1508 (the traditional date cited for his birth is 1479 ).

33 Émile Dacier, 'L'atelier des “reliures Louis xII".' Compare Plate vI, which has also been made with stamps A, B, C, E, and F (23-4). The lower plate of the binding is also reproduced as Fig. 2 in Guignard's 'Notes et hypothèses.'

34 Jacques Guignard, 'L'atelier de reliures Louis XII (Blois or Paris?) et l'atelier de Simon Vostre,' in Studia bibliographica in honorem Herman de la Fontaine Verwey (Amsterdam: H. Hertzberger, 1966), 202-39. See also Paul Needham, Twelve Centuries of Bookbinding 400-I600 (New York and London: Pierpont Morgan Library and Oxford University Press, 1979/, $n^{\circ} 40,135-9$.

35 See H.D. Saffrey, 'Sur une édition de Suétone parue à Lyon en octobre I 508,' Bibliothèque d'Humanisme et Renaissance 34 (1972): 427-34; 430.

36 Hobson, Humanists and Bookbinders, I $15-6$.

37 Renouard, Annales, no 27; Baudrier, Bibliographie Lyonnaise viI, 23.

38 Latin text and French translation given by Saffrey |'Sur une édition de Suétone,' 430): 'documenta principibus quae ad imperia recte administranda sequaerentur, exempla quae legentes declinarent.' The best biographical information on d'Argile I know of is given on p. 429 , n. Io.

39 Saffrey, 43I-2.

40 A Bolognese edition was published in 1506, the year when Argile was teaching there.

4I See Catalogue de la Bibliothèque nationale, t. I80 (I952), col. 336-40; Catalogue of the British Library, Vol. 3 I 7 (I986), 39-40. I have also made use of a microfiche copy of the British Library's Incunabula Short-Title Catalogue.

42 Saffrey, 'Sur une édition de Suétone,' 430. The term 'enchyridion' had been used on several occasions by Aldus (see Fletcher, New Aldine Studies, 88).

43 Renouard, Annales, 3 Io, n 32; Baudrier, Bibliographie Lyonese viII, 420.

44 The title of the epistle reads: 'Godofredus Torinus Bituricus Joanni Rosselletto, literarum amantissimo, S.D.P.'

45 A. Bernard, Geofroy Tory, 2nd ed. (Paris: Librairie Tross, I865), 7-8. For Tory's relations with the Lallemant family, see Myra D. Orth, 'Progressive Tendencies in French Illumination: 1515-1530: Godefroy le Batave and the 1520 s Hours Workshop,' Ph.D. Dissertation, New York University, I976 (Ann Arbor: University Microfilm), 382-3, n. 53 .

46 Bernard, Geofroy Tory, 8: 'ipsum (the manuscript for his edition of Quintilian), ut jussisti, a Parrhisiis Lugdunum misi.' 
47 Rés. 810654 . The best description of the work of this binder is to be found on pp. II 6-7 of Ernst Kyriss's 'Parisian Panel Stamps between 1480 and 1530,' Studies in Bibliography 8 (1955): 113-24. A rubbing of the St. Barbara and St. Sebastian stamp is given as Fig. 6.

48 See E.P. Goldschmidt, Gothic and Renaissance Bookbindings (London: E. Benn, 1928|, Vol. 2, $\mathrm{n}^{\circ}$ 67, Plate xxIx; Denise Gid, Catalogue des reliures françaises estampées à froid ( $\mathrm{XV}^{e}-\mathrm{XVI}{ }^{e}$ siècle) de la Bibliothèque Mazarine (Paris: CNRs, 1984), $\mathrm{n}^{\circ} 452$ and Planche $23\left(=S^{t}+2\right)$. It is interesting that two other bindings with the Sainct Yves panel are on copies of editions edited by Tory, to wit, the Cosmographia by Aeneas Sylvius (Paris, I 509), cited by Goldschmidt, and the Liber de re aedificatoria decem by Alberti (Paris, 15 I2) at the Mazarine (16038 D Rés.).

49 Geneva, Bibliothèque publique et universitaire, $\mathrm{Ha} 642$ Rés.

50 Otto Mazal, Europäische Einbandkunst aus Mittelalter und Neuzeit (Graz: Akademische Druck- und Verlagsanstalt, 1970), Abb. 63.

5 I To date, most of the bindings by Julien des Jardins are on books printed between I 505 and 1512 (see Kyriss, 'Parisian Panel Stamps,' I $16-17$ ).

52 Needham, following Goldschmidt, has assigned it to Paris (Twelve Centuries of Bookbindings, $\mathrm{n}^{\circ} 37, \mathbf{1 2 8 - 3 0}$.

53 See Shaw, 'The Lyons Counterfeit,' 12 I.

54 I have found no new information on Murchius (or Murchio). He claims to be a medical doctor from Genoa ('Genuensis'). He signed the preface to an edition of Arnaldus de Villa Nova printed in Lyons in March 1504 (Bibliographie Lyonnaise viI, p. 2I) and was in Blois when he signed the preface to his Sallust.

55 I have not looked closely at other centres. Note, however, the existence of a fairly contemporary panel-stamp binding by the Antwerp binder, Peter van Else (alias van den Winckel) on the Morgan Library copy of the 1508 Suetonius (PML 29236). English bindings have been noted on the following two early Lyonese editions: the copy of the c. 1506 Theophrastus housed in the Bodleian/Lister A 233; J.B. Oldham, Blind Panels of English Binders (Cambridge: Cambridge University Press, I958|, I6 and Pl. viI, Stamp AN. 9|; and their copy of the I 5 Io Quintilian (8 $8^{\circ}$.C.59 Linc; Oldham, Panels RO. I9 and BIB. 4). See also Mirjam Foot, The Henry Davis Gift: A Collection of Bookbindings. Vol. Ir. A Catalogue of Northern-European Bindings (London: British Library, 1978), 37-8, $\mathrm{n}^{\circ}$ I I. Such bindings do not necessarily prove that Lyonese Aldines were on sale in those cities; copies could have been bought elsewhere and bound in Antwerp or London.

56 Needless to say, the number of bindings I have considered compared to the total number of copies printed, or even of those that have come down to us, is miniscule, and has absolutely no statistical significance. They can, however, suggest hypotheses, which I have tried to elaborate on here.

57 See references to A.F. Johnson and A. Tinto above in note 14.

58 Inventaire chronologique des éditions Parisiennes du XVI ${ }^{e}$ siècle, compiled by B. Moreau, Vol. II, (Paris: Imprimerie municipale, I977), nos I 85 (Persius), 400 (Lucan), 430 (Plautus), 689 (Persius). Even Moreau had originally adopted 
the earlier dating (Vol. I, I 506, $\mathrm{n}^{\circ}$ I 47), but she corrected herself in Vol. II $\left(\mathrm{n}^{\circ}\right.$ I 85 - c. I5II). One of these editions, that of Plautus (c. I5I2), was copied by the Lyonese in 1513 , who were not yet about to be outdone. It should be noted that Le Rouge had printed a Latin Horae in italic c. 15 10, something that the Lyonese had tried in about 1505, as noted by Shaw ('The Lyons Counterfeit,' 125; see also 122 ).

59 Juvenal/Persius: Bodleian, Rylands, Harvard; Philostratus: BL, BNF, Rylands; Cicero: BNF, Cambridge, Rylands.

6o Dante: Harvard and perhaps another elsewhere; Cicero (Ep. fam.): Florence BM, BNF; Petrarch: BNF (Renouard cited two copies).

6I Valerius Maximus: Rylands; Juvenal/Persius: Bodleian; Virgil; Rylands; Horae: BL.

62 See, in particular, the copies in the BNF.

63 I note the existence of two other volumes with one or more illuminated pages: an illuminated text-initial leaf, perhaps from the Low Countries, in the Morgan Library copy of the c. I 504 Philostratus (PML 1 524); and five illuminated borders, surely of French origin, in a composite volume comprising the c. 1502 JuvenalPersius and the c. 1503 Horace, at the Bodleain Library (Auct. 2R6.10).

64 The material presented above should eventually be integrated into the general picture of possible Aldine influences in Paris as presented by Lowry (The World of Aldus Manutius, 279-85): the presence of Lefèvre d'Étaples and Guillaume Budé in Venice in the early years of the century; the sojourn of Janis Lascaris and Fra Giocondo in Paris during I 508-09; Gourmont's Greek imprints based on Aldine texts from 1507-14; and Aleander's courses in Greek given in Paris in the years I 509-14. But all of this would require another article.

65 Annales de l'imprimerie des Alde (Paris: A.-A. Renouard, I803), II, 194-5.

66 See, for instance, CAMAC V, 66-95. 